\title{
Computation of Runoff by SCS-CN Method from Micro- watersheds of Urmodi Basin in Maharashtra State Using RS and GIS
}

\author{
S. B. Nandgude ${ }^{1}$, G. S. Jadhav ${ }^{1}$, S.S.Shinde ${ }^{1 *}$, D. M. Mahale ${ }^{2}$, T. Bhattacharyya ${ }^{2}$ and S. S. Wandre ${ }^{3}$ \\ ${ }^{\prime}$ Department of Soil and Water Conservation Engineering, CAET, Dapoli; Dr. B. S. K. K. V, \\ Dapoli 415 712, India \\ ${ }^{2}$ Vice-Chancellor, Dr. Balasaheb Sawant Konkan Krishi Vidyapeeth, Dapoli 415 712, India \\ ${ }^{3}$ Department of Soil and Water Engineering CAET, Junagadh Agril. University, Junagadh 362001, India
}

\begin{abstract}
Flood is a natural or manmade phenomenon and timely and accurate forecasting of flood is very important however, forecasting of flood is a difficult task due to influence of rainfall-runoff process which depends on various factors. Estimation of surface runoff in a watershed is based on the rate of received precipitation and discharge at the outlet. In this study runoff from micro-watersheds of Urmodi basin in Maharashtra state was computed by Soil Conservation Service-Curve Number (SCS-CN) method using RS and GIS techniques. Various thematic maps such as soil map, land use/land cover, stream order, slope etc. were prepared using remote sensing and GIS. Daily rainfall data was used for determination of runoff. Antecedent moisture conditions for different CNs were determined with the help of combined land use land cover and hydrologic soil group map in (ArcGIS) GIS environment. Results showed that the highest runoff for Bharatgaon and Nagthane micro-watersheds was $46.20 \mathrm{~mm}$ and $54 \mathrm{~mm}$ respectively. Total runoff depth for the year 2014 was computed as $215.05 \mathrm{~mm}$ for Bharatgaon micro-watershed and 277.68 $\mathrm{mm}$ for Nagthane micro-watershed. Different soil and water conservation measures and water harvesting structures were recommended to control soil erosion and to harness the surface runoff.
\end{abstract}

Keywords: GIS, Remote Sensing, Runoff, SCS-CN method.

\section{Introduction}

In recent years, the global climate is changing with accelerated rate causing extreme weather events like drought and flood more frequently. This can have significant impact on agriculture, natural resources, overall ecosystem and livelihood. Rainfall-runoff are the important components contributing significantly to the hydrological cycle. In surface hydrology, rainfall-runoff processes play a vital role. The runoff estimation is one of the most important phenomena in hydrologic design of soil water conservation structures. It is also an important aspect in engineering planning, environmental impact assessment, flood forecasting and water balance calculations (Balvanshi and Tiwari 2014). Now-a-days applications of Remote Sensing (RS) and Geographic Information
Systems (GIS) techniques are increasingly used for planning, development, and management of natural resources at regional, national and international level. For an aggregated study of runoff modeling, remote sensing and GIS have gained significance in the determination of the runoff volume of watershed. RS and GIS are the efficient tools for managing natural disasters, design and construction of water conservation structure and flood forecasting / regulation. GIS is widely used for the preparation of most of the input data required by the Soil Conservation Service-Curve Number (SCS) curve number method (Sunder et al. 2010). The statistical analysis indicates that the SCS CN method can be applied to predict runoff depths of ungauged watershed (Buthkar and Regulwar 2015). 


\section{Materials and Methods}

Studyarea

Urmodi is the tributary of Krishna river, and its catchment lies in Satara district of Maharashtra. The Bharatgaon micro-watershed of this catchment lies between $17^{\circ} 35^{\prime} 54^{\prime \prime} \mathrm{N}$ to $17^{\circ} 37^{\prime} 3 " \mathrm{~N}$ latitude and $74^{\circ} 1 ' 33^{\prime \prime} \mathrm{E}$ to $74^{\circ} 2^{\prime} 13^{\prime \prime} \mathrm{E}$ longitude. The Bharatgaon micro-watershed has an area of 123 ha. Nagthane micro watershed with total area of 264 ha, located between $17^{\circ} 33^{\prime} 22^{\prime \prime} \mathrm{N}$ to $17^{\circ} 33^{\prime} 55^{\prime \prime} \mathrm{N}$ latitude and $74^{\circ} 0^{\prime} 43^{\prime \prime} \mathrm{E}$ to $74^{\circ} 2^{\prime} 25^{\prime \prime} \mathrm{E}$ longitude. Government of Maharashtra has coded Urmodi catchment as watershed KR-14. Average daily temperature in this zone is about $27^{\circ} \mathrm{C}$ and May is the hottest month. Annual rainfall in the basin is of the order of $1250-1800 \mathrm{~mm}$. The soil texture in the watershed varies from clay to clay loam.
Climate of the study area is tropical with three distinct seasons. The location map of the study area is shown in (Fig. 1).

\section{Data collection}

Toposheets of study area were obtained from GIS unit cell, Commissionorate of Agriculture, Pune. The cloud free digital satellite data of the study area were obtained from the Indian Remote Sensing Satellite (IRS-1D LISS- III) digital data (Row no-147, Path no48) to prepare land use/land cover (LU/LC) maps of the watershed. A $30 \mathrm{~m} \times 30 \mathrm{~m}$ resolution $\mathrm{DEM}$ was downloaded from BHUVAN website for the study area. The Soil map on 1:50,000 scale and soil characteristics data were obtained from the Maharashtra Remote Sensing Applications Centre (MRSAC), Nagpur. The daily rainfall data of study area for year 2014 were collected from Hydrology User Group, Nashik.

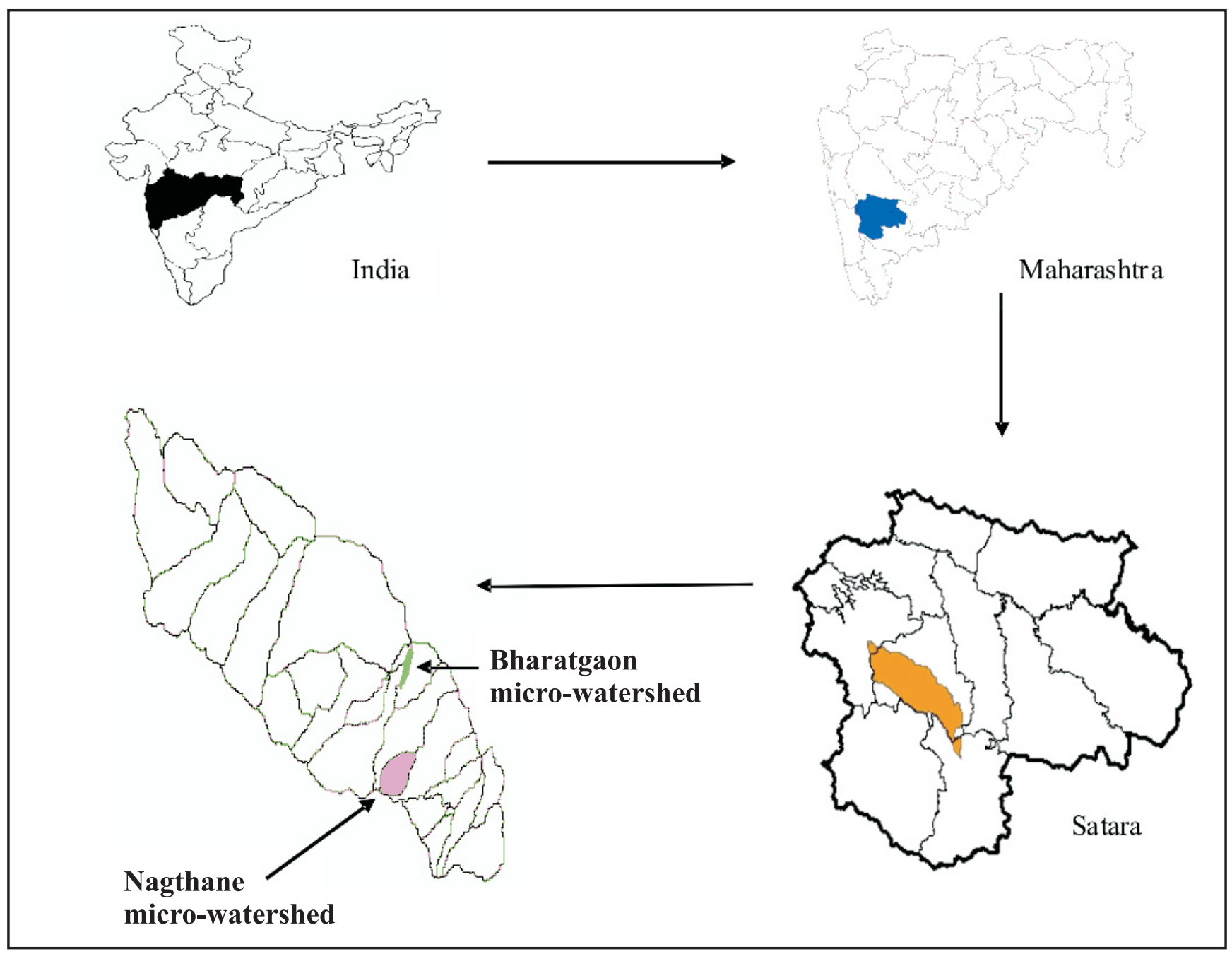

Fig. 1. Location map of study area 
Table 1. Rainfall limits for estimating antecedent moisture conditions

\begin{tabular}{|c|c|c|}
\hline \multirow[b]{2}{*}{ AMC } & \multicolumn{2}{|c|}{ Total Rain in Preceding 5 days $(\mathrm{mm})$} \\
\hline & Dormant Season & Growing Season \\
\hline $\mathrm{I}$ & $<13$ & $<36$ \\
\hline II & 13 to 28 & 36 to 53 \\
\hline III & $>28$ & $>53$ \\
\hline
\end{tabular}

Methodology

In this study, various data such as satellite images, digital elevation model (DEM), soil map and rainfall data were used for estimation of surface runoff. Land use/land cover map for the month of November was prepared using LISS III data. Slope map of the study area was derived from DEM using ERDAS imagine software. The hydrological soil group (HSG) map (1:50,000 scale) was generated with the help of soil texture map. The runoff estimates for different combinations of soil group, land use classes and Antecedent Moisture Condition (AMC) classes were estimated by adopting the procedure of 'SCS-CN method'. The Soil Conservation Service (Soil Conservation Service 1985) for conditions prevailing in the United States originally developed the curve number method. Since then, it has been adapted to conditions in other parts of the world. Runoff depth was computed using following equation (Nayak et al. 2012).

$$
Q=\frac{(P-0.3 S)^{2}}{P+0.7 S}
$$

Where,

$$
\begin{aligned}
& Q=\text { Runoff, } \mathrm{mm} \\
& P=\text { Rainfall, } \mathrm{mm} \\
& S=\text { Potential maximum retention (ability } \\
& \text { of a watershed to abstract and }
\end{aligned}
$$$$
\text { retain storm precipitation), } \mathrm{mm} \text {. }
$$

The potential maximum retention $(\mathrm{S})$ and watershed characteristics are related through an intermediate parameter, called curve number $(C N)$. It is an index that represents the combination of hydrological soil group, land use pattern, and antecedent moisture conditions and is expressed as (Muthu and Santhi 2015).

$$
\mathrm{S}=\frac{25400}{\mathrm{CN}}-254
$$

$\mathrm{CN}$ has a range of $100 \geqslant \mathrm{CN} \geqslant 0 . \mathrm{A} \quad \mathrm{CN}=100$ represents a condition of zero potential retention and $\mathrm{CN}=0$ represents an infinitely abstracting catchment with $\mathrm{S}=\infty$.

\section{Antecedent Moisture Condition}

Antecedent Moisture Condition (AMC) is defined as the wetness index of soil. It refers to the moisture content present in the soil at the beginning of the rainfall runoff event under consideration (Khaddor and Alaoui 2014). AMC is determined on the basis of five days antecedent rainfall amounts (Table 1).

\section{Estimation of $\mathbf{C N}$ :}

For a watershed that consists of several soil types and land uses, a composite $\mathrm{CN}$ is calculated as (Nasiri and Alipur 2014)

$$
\mathrm{CN}_{\text {composite }}=\frac{\Sigma(\mathrm{Ai} \times \mathrm{CNi})}{\Sigma \mathrm{Ai}}
$$

Where,

$C N_{\text {composite }}=$ the composite $\mathrm{CN}$ used for runoff volume computations

$i=$ an index of watersheds sub-divisions of uniform land use and soil type

$C N i=$ Curve number for sub-division $i$ and

$A i=$ the drainage area of subdivision $i$

$\mathrm{CN}$ for AMC I am calculated as:

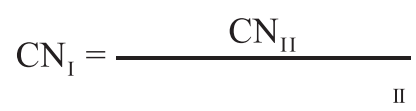

$\mathrm{CN}$ for AMC-III is calculated as:

$$
\mathrm{CN}_{\text {III }}=\frac{\mathrm{CN}_{\text {II }}}{\text { II }}
$$


Table 2. Curve number values for different land use categories and HSGs (Khaddor and Alaoui 2014)

\begin{tabular}{|c|c|c|c|c|}
\hline \multirow[t]{2}{*}{ Land Use } & \multicolumn{4}{|c|}{ Hydrologic Soil Group } \\
\hline & $\mathbf{A}$ & B & $\mathrm{C}$ & D \\
\hline Build Up & 76 & 86 & 90 & 93 \\
\hline $\begin{array}{l}\text { Agriculture } \\
\text { Land }\end{array}$ & 49 & 69 & 79 & 84 \\
\hline Tree cover & 41 & 55 & 69 & 73 \\
\hline Forest & 26 & 40 & 58 & 61 \\
\hline Wasteland & 71 & 80 & 85 & 88 \\
\hline Water bodies & 100 & 100 & 100 & 100 \\
\hline
\end{tabular}

\section{Results and discussion}

\section{Land use land cover map}

The LU/LC in the Bharatgaon microwatershed area was classified into three classes: (i) Agriculture (ii) Forest and (iii) Wasteland (Fig. 2). Similarly the LU/LC in Nagthane micro-watershed was classified into four classes (Fig. 3). Land use/ land cover pattern of Bharatgaon micro-watershed revealed that majority of watershed land comes under agriculture class (105.92 ha), 86 per cent of the total

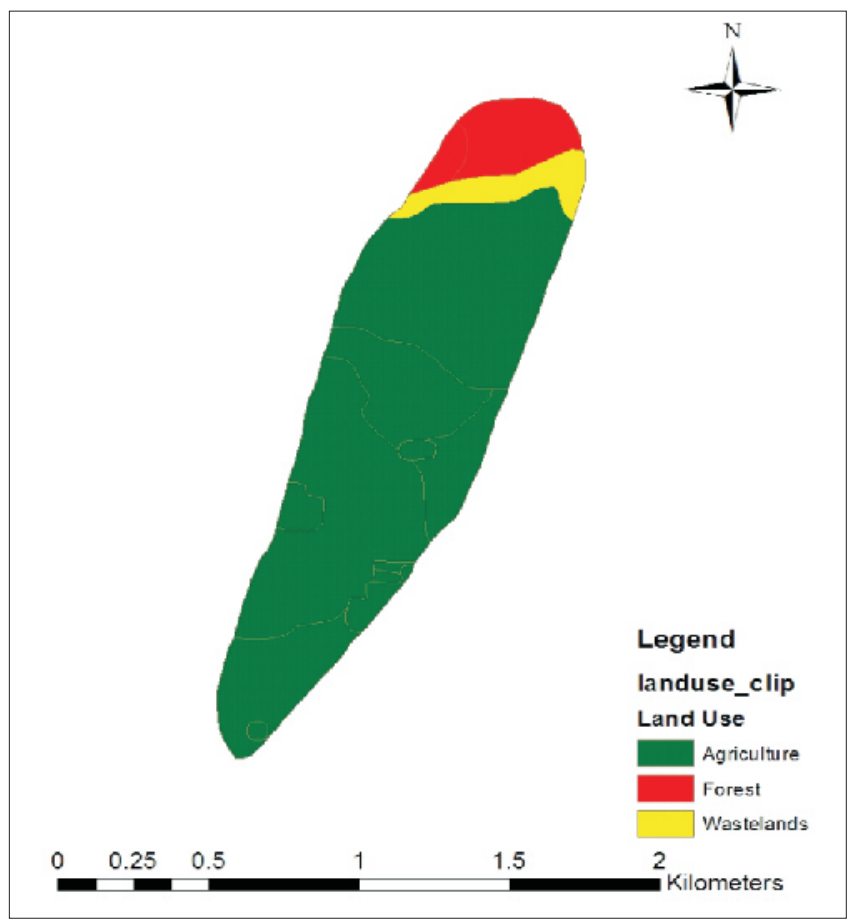

Fig. 2. Land use land cover map of Bharatgaon micro-watershed area of watershed. Next dominant class is forest (10.92 ha) which covers about 8.50 per cent of total area followed by wasteland ( $6.37 \mathrm{ha}$ ) which is about 5.50 per cent of total area). The Nagthane micro-watershed showed similar kind of LU/LC pattern. The agricultural class covers 230 ha of the total area which is about 80.98 per cent of the total area. Wasteland area covers about 11.26 per cent of area. Forest and build up land covers 14 ha and 8 ha respectively which is about 5.30 per cent and 2.81 per cent of the total area respectively.

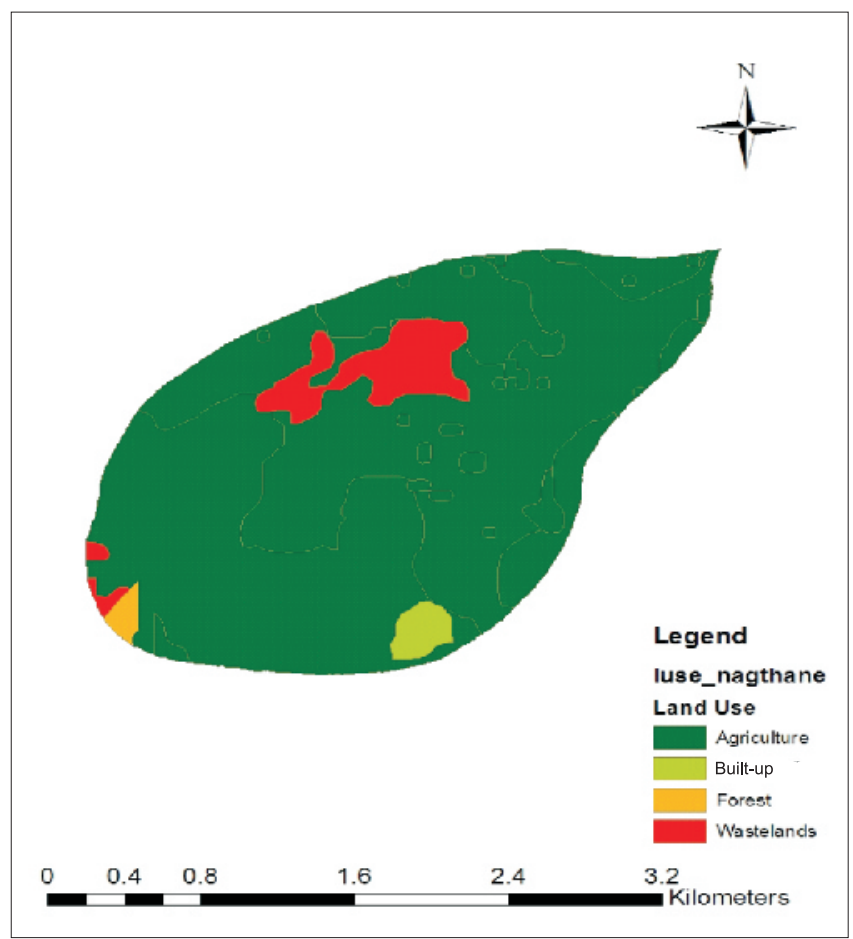

Fig. 3. Land use land cover map of Nagthane micro-watershed 


\section{Digital Elevation Model (DEM)}

Digital Elevation model (DEM) is a simple, regularly spaced grid of elevation points. DEM of the study area was downloaded from web portal of National Remote Sensing centre and it was used to generate the slope map of micro watersheds (Fig. 4).

\section{Drainage network map}

Drainage network map of the study area was prepared by using DEM (Fig. $4 \& 5$ ). In Nagthane micro-watershed, the first order stream covers total length of $9 \mathrm{~km}$ which is 55.38 per cent of the total drainage length. The second order stream has total length of $5 \mathrm{~km}$ which is 30.76 per cent of the total length, the third order stream has total length of $2.25 \mathrm{~km}$ ( $13.84 \%)$. Bharatgaon area is mostly drained by the first order streams having maximum drainage length of $2.74 \mathrm{~km}$, which covers about 57.56 per cent of total length of drainage. Second order has $2.02 \mathrm{~km}$ length. It is 42.43 per cent of total length of drainage.

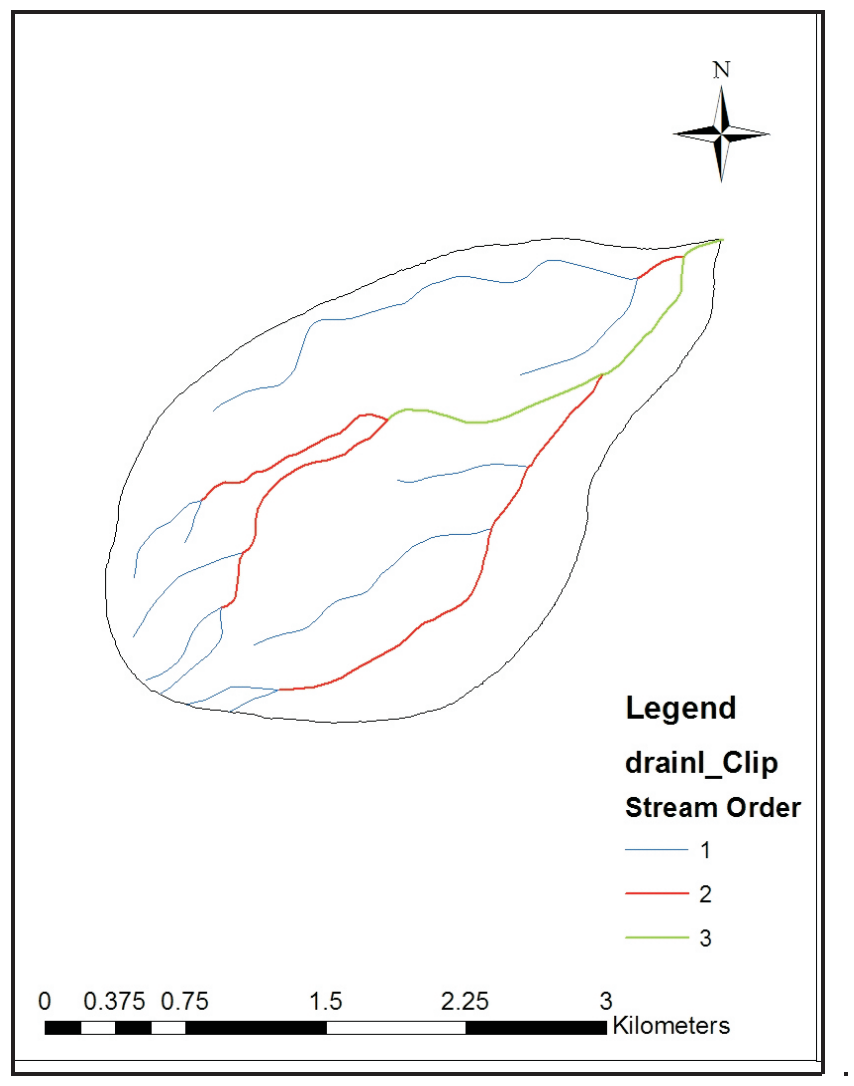

Fig. 4. Stream order map of Nagthane micro watershed

\section{Runoff estimation by SCS-CN method}

In SCS-CN method, the $\mathrm{CN}$ values used were $\mathrm{CN}_{\mathrm{I}}=64.54, \mathrm{CN}_{\mathrm{II}}=80.68$ and $\mathrm{CN}_{\mathrm{III}}=91.68$ for AMC-I, AMC-II and AMC-III respectively as inputs to compute daily runoff. The individual composite curve number was computed for study area for AMC II condition. Then using equation (4) and (5) $\mathrm{CN}_{\mathrm{I}}$ and $\mathrm{CN}_{\mathrm{III}}$ were computed. The results of runoff computation for Bharatgaon micro-watershed using SCS curve number method are shown in table 3 . Total 14 runoff events were observed where moderate runoff was recorded in the watershed. The watershed soil belongs to HSG, C and D which have texture as clay, clay loam, gravelly clay loam and gravely clay. The specific maximum retention for the $1^{\text {st }}$ event was observed to be $23.05 \mathrm{~mm}$ for a curve number of 91.68 which showed the AMC III condition and yielded the runoff of $3.59 \mathrm{~mm}$. The highest runoff of the season occurred during the $2^{\text {nd }}$ event showed the AMC-III condition which was accounted to be 46.20 mm (Table 3 and Fig. 6). The $3^{\text {rd }}, 7^{\text {th }}, 11^{\text {th, }}, 12^{\text {th }}, 13^{\text {th }}$ and

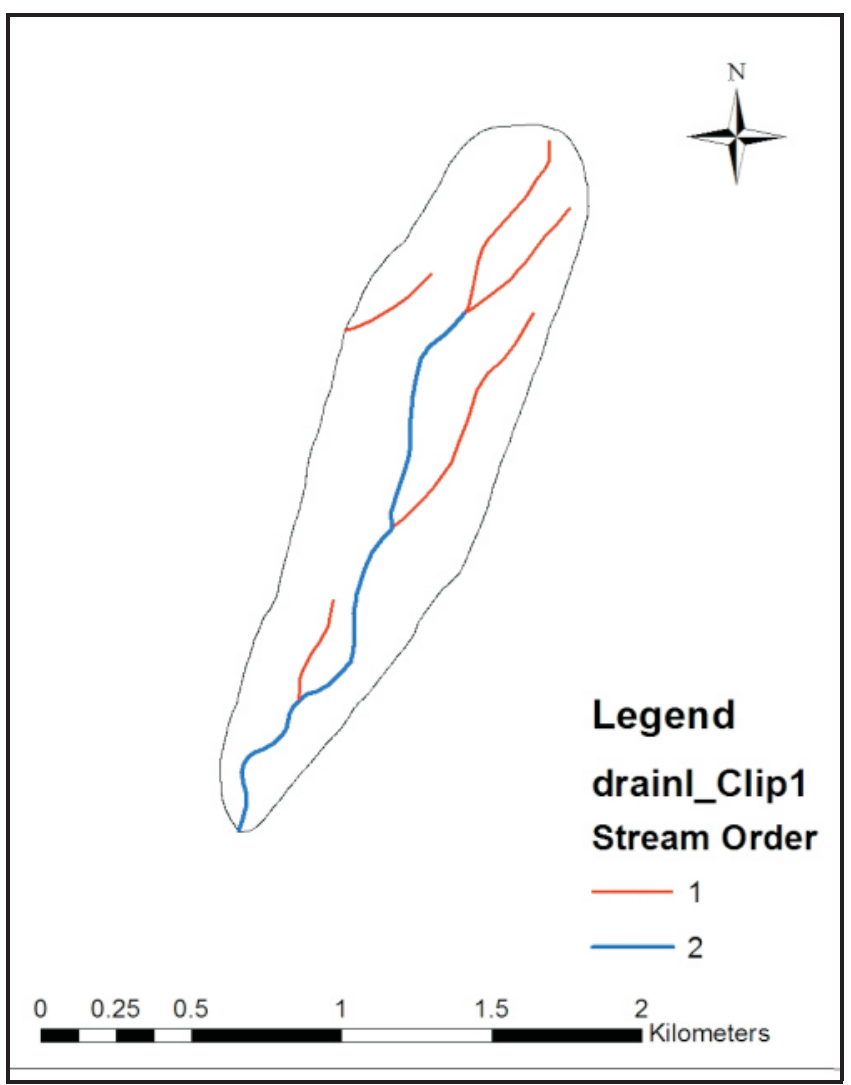

Fig. 5. Stream order map of Bharatgaon micro watershed 
$14^{\text {th }}$ rainfall events showed the AMC-I condition and yielded runoff of $6.95,7.52,5.39,8.76,5.72$ and 8.86, respectively. Similarly the lowest selected rainfall event occurred on $14^{\text {th }}$ event which yielded runoff of $8.76 \mathrm{~mm}$. The total annual rainfall of the area was $713.50 \mathrm{~mm}$ with the runoff of about $215.05 \mathrm{~mm}$ for the year 2014 . Similarly for the Nagthane micro-watershed 14 runoff events were observed.. The curve number for different AMC conditions were $\mathrm{CN}_{\mathrm{I}}=72.43, \mathrm{CN}_{\mathrm{II}}=85.70, \mathrm{CN}_{\mathrm{III}}=$ 93.63 (Table 4).

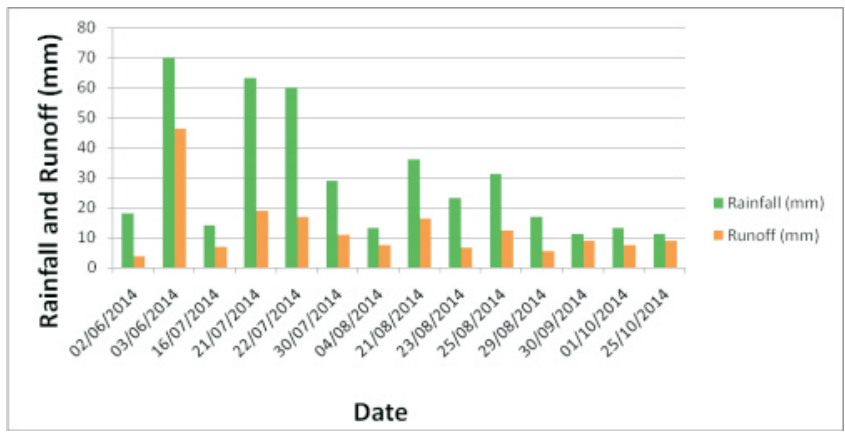

Fig. 6. Daily rainfall and runoff in Bharatgaon micro-watershed

Table 3. Daily rainfall and runoff values for Bharatgaon micro watershed

\begin{tabular}{c|c|c|c|c|c|c}
\hline Sr. no & Date & $\begin{array}{c}\text { Rainfall } \\
(\mathbf{m m})\end{array}$ & $\begin{array}{c}\text { Specific } \\
\text { Retention }\end{array}$ & CN & AMC & $\begin{array}{c}\text { Runoff } \\
(\mathbf{m m})\end{array}$ \\
\hline 1 & $2 / 06 / 2014$ & 18 & 23.05 & 91.68 & III & 3.59 \\
2 & $3 / 06 / 2014$ & 70 & 23.05 & 91.68 & III & 46.20 \\
3 & $16 / 07 / 2014$ & 14 & 139.55 & 64.54 & I & 6.95 \\
4 & $21 / 07 / 2014$ & 63 & 60.82 & 80.68 & II & 18.97 \\
5 & $22 / 07 / 2014$ & 60 & 60.82 & 80.68 & II & 16.99 \\
6 & $30 / 07 / 2014$ & 29 & 23.05 & 91.68 & III & 10.80 \\
7 & $4 / 08 / 2014$ & 13 & 139.55 & 64.54 & I & 7.52 \\
8 & $21 / 08 / 2014$ & 36 & 23.05 & 91.68 & III & 16.22 \\
9 & $23 / 08 / 2014$ & 23 & 23.05 & 91.68 & III & 6.61 \\
10 & $25 / 08 / 2014$ & 31 & 23.05 & 91.68 & III & 12.30 \\
11 & $29 / 08 / 2014$ & 17 & 139.55 & 64.54 & I & 5.39 \\
12 & $30 / 09 / 2014$ & 11 & 139.55 & 64.54 & I & 8.76 \\
13 & $1 / 10 / 2014$ & 13 & 139.55 & 64.54 & I & 7.52 \\
14 & $25 / 10 / 2014$ & 11 & 139.55 & 64.54 & I & 8.76 \\
\hline
\end{tabular}

Table 4. Daily runoff values for Nagthane micro-watershed

\begin{tabular}{l|l|l|l|l|l|l}
\hline Sr. no & Date & $\begin{array}{l}\text { Rainfall } \\
(\mathbf{m m})\end{array}$ & $\begin{array}{l}\text { Specific } \\
\text { Retention }\end{array}$ & CN & AMC & Runoff (mm) \\
\hline 1 & $2 / 06 / 2014$ & 22 & 17.28 & 93.63 & III & 8.29 \\
2 & $3 / 06 / 2014$ & 73 & 17.28 & 93.63 & III & 54.0 \\
3 & $21 / 07 / 2014$ & 70 & 17.28 & 93.63 & III & 51.17 \\
4 & $22 / 07 / 2014$ & 63 & 17.28 & 93.63 & III & 44.51 \\
5 & $23 / 07 / 2014$ & 40 & 17.28 & 93.63 & III & 23.26 \\
6 & $30 / 07 / 2014$ & 29 & 17.28 & 93.63 & III & 13.80 \\
7 & $21 / 08 / 2014$ & 40 & 17.28 & 93.63 & III & 23.26 \\
8 & $25 / 08 / 2014$ & 33 & 17.28 & 93.63 & III & 17.15 \\
9 & $19 / 09 / 2014$ & 10 & 96.68 & 72.43 & I & 4.64 \\
10 & $30 / 09 / 2014$ & 11 & 96.68 & 72.43 & I & 4.12 \\
11 & $1 / 10 / 2014$ & 13 & 96.68 & 72.43 & I & 3.17 \\
12 & $25 / 10 / 2014$ & 15 & 96.68 & 72.43 & I & 2.37 \\
13 & $14 / 11 / 2014$ & 30 & 17.28 & 93.63 & III & 14.62 \\
14 & $15 / 11 / 2014$ & 53 & 42.30 & 85.70 & II & 19.63 \\
\hline
\end{tabular}




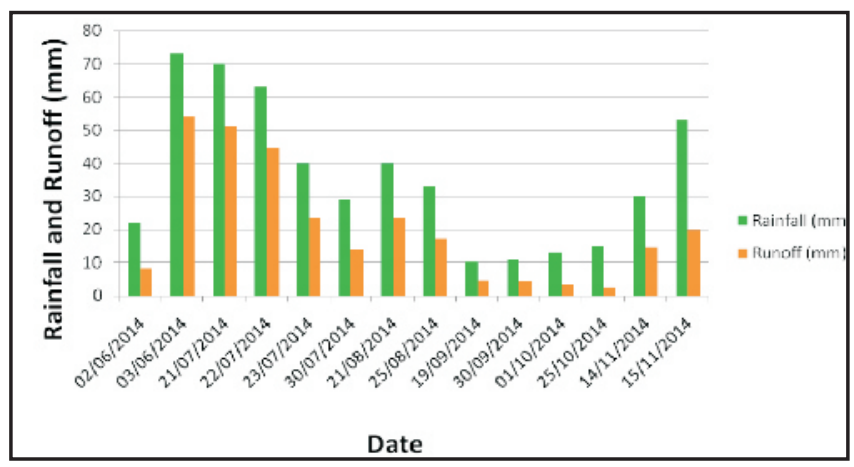

Fig. 7. Daily rainfall and runoff in Nagthane micro-watershed

The highest rainfall occurred during $2^{\text {nd }}$ event which was about $73 \mathrm{~mm}$ and generated runoff of $54 \mathrm{~mm}$. The maximum retention for $2^{\text {nd }}$ event was $17.28 \mathrm{~mm}$ and the $\mathrm{CN}$ was 93.63 which represent AMC-III condition. The lowest rainfall occurred during $9^{\text {th }}$ event yielded $4.64 \mathrm{~mm}$ runoff with maximum retention of $96.68 \mathrm{~mm}$ which represents AMC-I condition (Table 4 \& Fig. 7). The total rainfall in the micro watershed was $860 \mathrm{~mm}$ which generated about total runoff of $277.68 \mathrm{~mm}$.

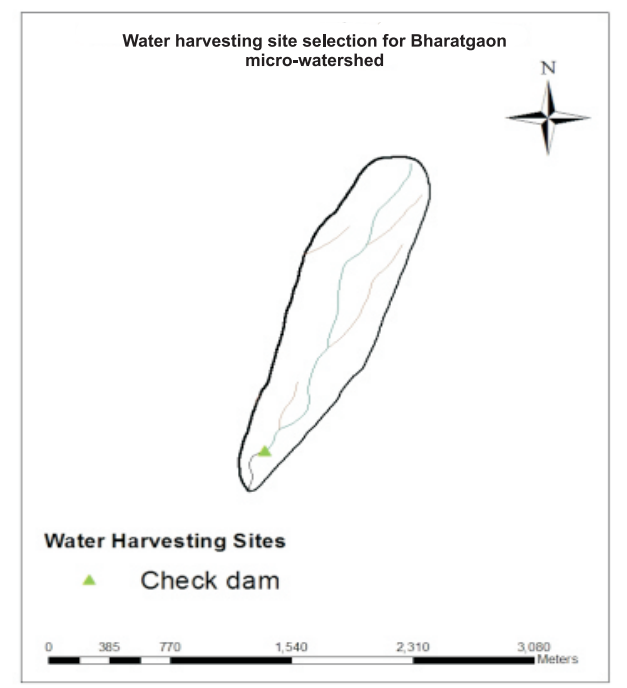

Fig. 8. Water harvesting site selection for Bharatgaon micro-watershed
Conservation and water harvesting planning for micro watersheds

Soil and water conservation measures for micro-watersheds were recommended based on climatic, soil (depth and texture) and topographical characteristics of micro-watershed (Srivastava et al., 2010). Earlier Bharatgaon and Nagthane microwatersheds were untreated i.e. no soil and water conservation measures. Different agronomical measures such as contour farming, strip cropping were suggested in Bharatgaon and Nagthane microwatershed to conserve the soil and water. Water harvesting structures such as check dam, percolation pond and farm pond were suggested based on runoff coefficient, slope map, rainfall and stream order map.

Length and height of proposed check dams, height of impounded water and water spread area behind the structures were measured at two locations in micro watersheds. Actual storage capacities of two structures (check dams) were determined. Design specifications of proposed check dams are given in table 5 .

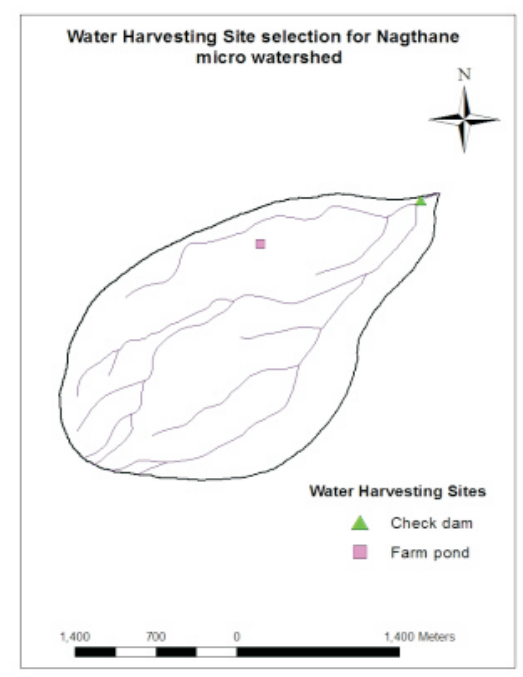

Fig. 9. Water harvesting site selection for Nagthane micro-watershed

Table 5. Design specifications of proposed check dams

\begin{tabular}{|c|c|c|c|c|c|c|}
\hline Sr.No. & Structure & Length (m) & Height (m) & $\begin{array}{c}\text { Average height of } \\
\text { impounded water(m) }\end{array}$ & $\begin{array}{c}\text { Water spread } \\
\text { area }\left(\mathbf{m}^{\mathbf{2}}\right)\end{array}$ & $\begin{array}{c}\text { Storage } \\
\text { capacity } \\
\left(\mathbf{m}^{\mathbf{3}}\right)\end{array}$ \\
\hline 1. & Check Dam & 21.5 & 2.5 & 2.27 & 1935 & 4392.45 \\
2. & Check Dam & 17 & 2.1 & 1.82 & 1530 & 2784.6 \\
\hline
\end{tabular}


Benefits on implementation of conservation measures and water harvesting structures

Recommended soil and water conservation measures are expected to reduce the slope length, protect the land from degradation and help to control the soil erosion from the watershed. Water harvesting structures will provide water storage for supplementary irrigation, help in moderating the floods in downstream areas and improve in-situ moisture conservation for increased biomass production. Besides, groundwater recharge is likely to improve due to adoption of different water harvesting structures and conservation measures in micro watersheds of Urmodi basin.

\section{Conclusions}

The integration of remote sensing data and the SCS CN model in a GIS environment provides a powerful tool for assessment of runoff for recommending suitable soil and water conservation measures in a watershed.

\section{References}

Balvanshi A. and Tiwari H.L. (2014). A comprehensive review of runoff estimation by the curve number method. International Journal of Innovative Research in Science, Engineering and Technology 3, 17480-17485.

Buthkar V. and Regulwar D. (2015). Computation of Runoff by SCS-CN Method and GIS. International
Journal of Engineering Studies and Technical Approach 01, 63-70.

Khaddor I. and Alaoui A.H. (2014). Production of a curve number map for hydrological simulation-case study: Kalaya watershed located in Northern Morocco. International Journal of Innovation and Applied Studies ISSN 2028-9324, 9, 1691-1699.

Muthu L.C. and Santhi M.H. (2015). Estimation of surface runoff potential using SCS-CN method integrated with GIS. Indian Journal of Science and Technology 8, 22-29.

Nasiri A. and Alipur H. (2014). Determination the curve number catchment by using GIS and remote sensing. International Journal of Environmental, Chemical, Ecological, Geological and Geophysical Engineering 8, 342-345.

Nayak T., Verma M.K. and Bindu H. (2012). SCS curve number method in Narmada basin. International Journal of Geomatics and Geosciences 3, 220-228.

Soil Conservation Service (1985). National Engineering Handbook. Section 4, Hydrology, U.S. Department of Agriculture, Washington DC.

Srivastava R.K., Sharma H.C. and Raina A.K. (2010). Suitability of soil and water conservation measures for watershed management using geographical information system. Journal of Soil and Water Conservation 9, 148-153. 